\title{
Top-cited articles in traumatic brain injury
}

\author{
Bhanu Sharma $^{\text {* }}$ and David Wyndham Lawrence ${ }^{2}$ \\ ${ }^{1}$ Toronto Rehabilitation Institute, University of Toronto, Toronto, ON, Canada \\ 2 Department of Family and Community Medicine, St. Michael's Hospital, University of Toronto, Toronto, ON, Canada
}

\section{Edited by:}

Aron K. Barbey, University of Illinois at Urbana-Champaign, USA

\section{Reviewed by:}

Arun Bokde, Trinity College Dublin, Ireland

Rachael Danielle Rubin, University of Illinois at Urbana-Champaign, USA

\section{*Correspondence:}

Bhanu Sharma, Toronto Rehabilitation Institute, University of Toronto, 550

University Avenue, Toronto, ON M5G 2A2, Canada

e-mail:bhanu.sharma@

mail.utoronto.ca
A review of the top-cited articles in a scientific discipline can identify areas of research that are well established and those in need of further development, and may, as a result, inform and direct future research efforts. Our objective was to identify and characterize the top-cited articles in traumatic brain injury (TBI). We used publically available software to identify the $50 \mathrm{TBI}$ articles with the most lifetime citations, and the 50 TBI articles with the highest annual citation rates. A total of 73 articles were included in this review, with 27 of the 50 papers with the highest annual citation rates common to the cohort of 50 articles with the most lifetime citations. All papers were categorized by their primary topic or focus, namely: predictor of outcome, pathology/natural history, treatment, guidelines and consensus statements, epidemiology, assessment measures, or experimental model of TBI. The mean year of publication of the articles with the most lifetime citations and highest annual citation rates was $1990 \pm 14.9$ years and $2003 \pm 6.7$ years, respectively. The 50 articles with the most lifetime citations typically studied predictors of outcome $(34.0 \%, 17 / 50)$ and were specific to severe TBI $(38.0 \%, 19 / 50)$. In contrast, the most common subject of papers with the highest annual citation rates was treatment of brain injury $(22.0 \%, 11 / 50)$, and these papers most frequently investigated mild TBI $(36.0 \%, 18 / 50)$. These findings suggest an intensified focus on mildTBI, which is perhaps a response to the dedicated attention these injuries are currently receiving in the context of sports and war, and because of their increasing incidence in developing nations. Our findings also indicate increased focus on treatment of TBI, possibly due to the limited efficacy of current interventions for brain injury. This review provides a cross-sectional summary of some of the most influential articles in $\mathrm{TBI}$, and a bibliometric examination of the current status of TBI research.

Keywords: traumatic brain injury, head injury, concussion, bibliometric, citation

\section{INTRODUCTION}

In an effort to improve clinical outcomes following traumatic brain injury (TBI), leading scientific institutions have pioneered an international, multidisciplinary research initiative (The Lancet, 2012). In particular, the Canadian Institutes of Health Research, the National Institutes of Health, and the European Commission leading research agencies within their respective jurisdictions have recently collaborated to fund and advance TBI research through the International Initiative for Traumatic Brain Injury Research (European Commission, 2012; The Lancet, 2012; The Lancet Neurology, 2013; Tosetti et al., 2013). This unprecedented effort at TBI-specific international collaboration and resource pooling is a testament to the global burden of this injury (The Lancet Neurology, 2013), and it is perhaps a response to calls for increased funding for brain injury research and greater networking between institutions studying TBI (Zitnay et al., 2008). The pressing need to advance TBI research is most evident when considering predictions that TBI will become the third leading cause of death and disability worldwide by the year 2020 (World Heath Organization, 2002; The Lancet, 2012).

Commitments to advance our understanding of TBI and the management strategies available to treat this injury will be effectuated by an increase in research activity (The Lancet, 2012). It is important, therefore, to examine current TBI literature and identify the areas of research that are well established and those in need of further development, as this may inform researchers and granting agencies where to focus future research efforts. Reviewing the literature with this aim is especially important considering that consensus statements report that our understanding of TBI has progressed further in some areas than in others (Zitnay et al., 2008).

One way to objectively identify a well-developed area of the literature is to measure the number of citations it has accumulated (Patsopoulos et al., 2005; Ponce and Lozano, 2010). Publications that are highly cited are well recognized, widely read and referenced, regularly discussed, and likely to be considered important within their respective subfields (Lipsman et al., 2014). Moreover, the number of times a publication is cited serves as a proxy for its influence within a discipline (Garfield, 1986; Lipsman et al., 2014). An analysis of the top-cited articles in a given field, therefore, provides clinicians and researchers with a cross-sectional summary of some of the most important work on a topic (Yang and Pan, 2006; Ibrahim et al., 2012; Lipsman and Lozano, 2012; Lipsman et al., 2014). Bibliometric citation analyses can also reveal the breadth (Lipsman et al., 2014) and existing patterns or themes within a literature (Rubin, 2004), while evaluating annual citation rates may indicate how the science is trending (Lipsman and Lozano, 2012). 
The primary objective of our review was to identify and characterize TBI publications that have (1) the greatest number of lifetime citations and (2) the highest annual citation rates. We categorized and analyzed top-cited articles according to characteristics such as their primary focus, sample, design, and country of correspondence. Other groups have conducted similar analyses within different areas of research (Yang and Pan, 2006; Lefaivre et al., 2010; Ponce and Lozano, 2010; Shadgan et al., 2010; Ibrahim et al., 2012; Lipsman and Lozano, 2012; Lipsman et al., 2014). Collectively, the publications reviewed here highlight some of the most influential articles in TBI, and also the studies that may be shaping the direction in which this growing field is heading.

\section{METHODS}

We used the publically available software Harzing's Publish or Perish v.4.6.3 (Harzing, 2007) to conduct our citation analysis. This software computes various citation metrics after collecting raw citation data through Google Scholar. It should be noted that other groups have conducted bibliometric citation analyses using Harzing's Publish or Perish (Lipsman and Lozano, 2012; Lipsman et al., 2014). Citation metrics are accurate to May 1, 2014.

Our search included a comprehensive set of terms. In particular, we searched for articles that contained the term "head trauma," "head injury," "head injuries," "head injured," "brain trauma," "brain injury," "brain injuries," "brain injured," "traumatic brain injury," "traumatic brain injuries," “TBI," “concussion," or "concussions" in the study title. We manually reviewed the full list of the top-cited TBI articles generated by Harzing's Publish or Perish (Harzing, 2007) in consecutive order until a total of 50 articles that met our inclusion and exclusion criteria (outlined below) were identified. We also sorted the data in Harzing's Publish or Perish (Harzing, 2007) by "citations/year" to identify the 50 TBI articles, meeting our inclusion and exclusion criteria, with the highest annual citation rates. There were no restrictions on date of publication.

To be included in our final sample, it was necessary for TBI to be the primary focus of the article (e.g., the article could not be about acquired brain injuries in general), the full article to be electronically accessible, and for the article to be peer reviewed. We included primary publications, consensus statements/guidelines, commentaries, and review articles. An article was excluded if it was not peer reviewed, and/or if it was a report or book chapter (Figure 1).

A grounded theory methodology (Strauss and Corbin, 1990) was used to code each article, with respect to overall focus/topic. After independently coding the same set of 40 articles (at which point data saturation was achieved), the authors met to reach a consensus on the categorization strategy and ensure that similar codes were being grouped together consistently. After coding articles from both citation cohorts (i.e., the 50 most-cited articles in TBI and the 50 articles with the highest annual citation rates), differences in coding were reconciled by debate until consensus was reached. Both cohorts of articles were analyzed similarly. Only descriptive statistics were performed.

\section{RESULTS}

The publications that comprise the two citation cohorts are listed in Tables 1 and 2. On average, the 50 most-cited articles in TBI accumulated a lifetime total of $834.8 \pm 248.8$ citations (range: 574-1645). The average annual citation rate of these papers was $48.0 \pm 43.4$ citations per year, with a range between 8.1 and 192.7. In contrast, the annual citation rate of the $50 \mathrm{TBI}$ papers that have accumulated the most citations per year since publication was $65.5 \pm 35.4$ citations per year (range: $39.1-192.7$ ). The absolute number of citations this latter cohort of papers accumulated since publication ranged from 169 to 1645 , with an average of $654.7 \pm$ 350.6 lifetime citations. Over half $(27 / 50,54.0 \%)$ of the publications with the highest annual citation rates were common to the 50 TBI papers with the most lifetime citations.

Most papers with the greatest number of lifetime citations were published over a 30-year span starting in the mid-1970s (mean year of publication: $1990 \pm 14.9$ years). Conversely, the majority of TBI-specific papers with the highest annual citation rates were published within the last 15 years (mean year of publication: $2003 \pm 6.7$ years) (Figure 2). Both citation cohorts are further characterized in Table 3.

All papers were classified into one of seven general categories. Table 4 provides the distribution of papers from both citation cohorts into these seven categories (and sub-categories where appropriate). A more detailed discussion of category-specific findings follows.

\section{PREDICTOR OF OUTCOME}

Of the 50 most frequently cited articles in TBI, 17 (17/50, 34.0\%) primarily studied predictors of outcome. Most predictor studies involved human subjects $(14 / 17,82.4 \%)$, with a subset focusing exclusively on athletes $(1 / 14,7.1 \%)$ and war veterans $(1 / 14$, $7.1 \%)$. Nearly half of all predictor articles $(8 / 17,47.1 \%)$ studied severe TBI, while five centered on mild TBI (5/17, 29.4\%); the remainder $(4 / 17,23.5 \%)$ were composed of a heterogeneous sample with respect to injury severity. None of the topcited studies investigating predictors of outcome were randomized control trials, although many were prospectively conducted $(15 / 17,88.2 \%)$.

Comparatively, of the 50 articles with the highest annual citation rates, only eight $(8 / 50,16.0 \%)$ investigated predictors of outcome. Of these eight studies, half $(4 / 8,50.0 \%)$ were common to the 50 top-cited articles in TBI. Most predictor studies in the citation rate cohort were prospectively conducted $(4 / 8,50.0 \%)$, and half of all predictor studies $(4 / 8,50.0 \%)$ focused on a specialty population (i.e., athletes or war veterans). However, in comparison to the cohort of papers with the most lifetime citations, a greater percentage of predictor studies with the highest annual citation rates were specific to mild TBI $(3 / 8,37.5 \%)$.

\section{PATHOLOGY/NATURAL HISTORY}

The 50 top-cited articles in TBI included 10 studies (10/50,20.0\%) primarily focused on characterizing pathological outcome following brain injury. Nine of the pathology papers $(9 / 10,90.0 \%)$ were primary research articles; the other was a review article $(1 / 10$, $10.0 \%)$. The majority of pathology articles were of a prospective design $(8 / 10,80.0 \%)$ and involved human subjects $(6 / 10,60 \%)$. 


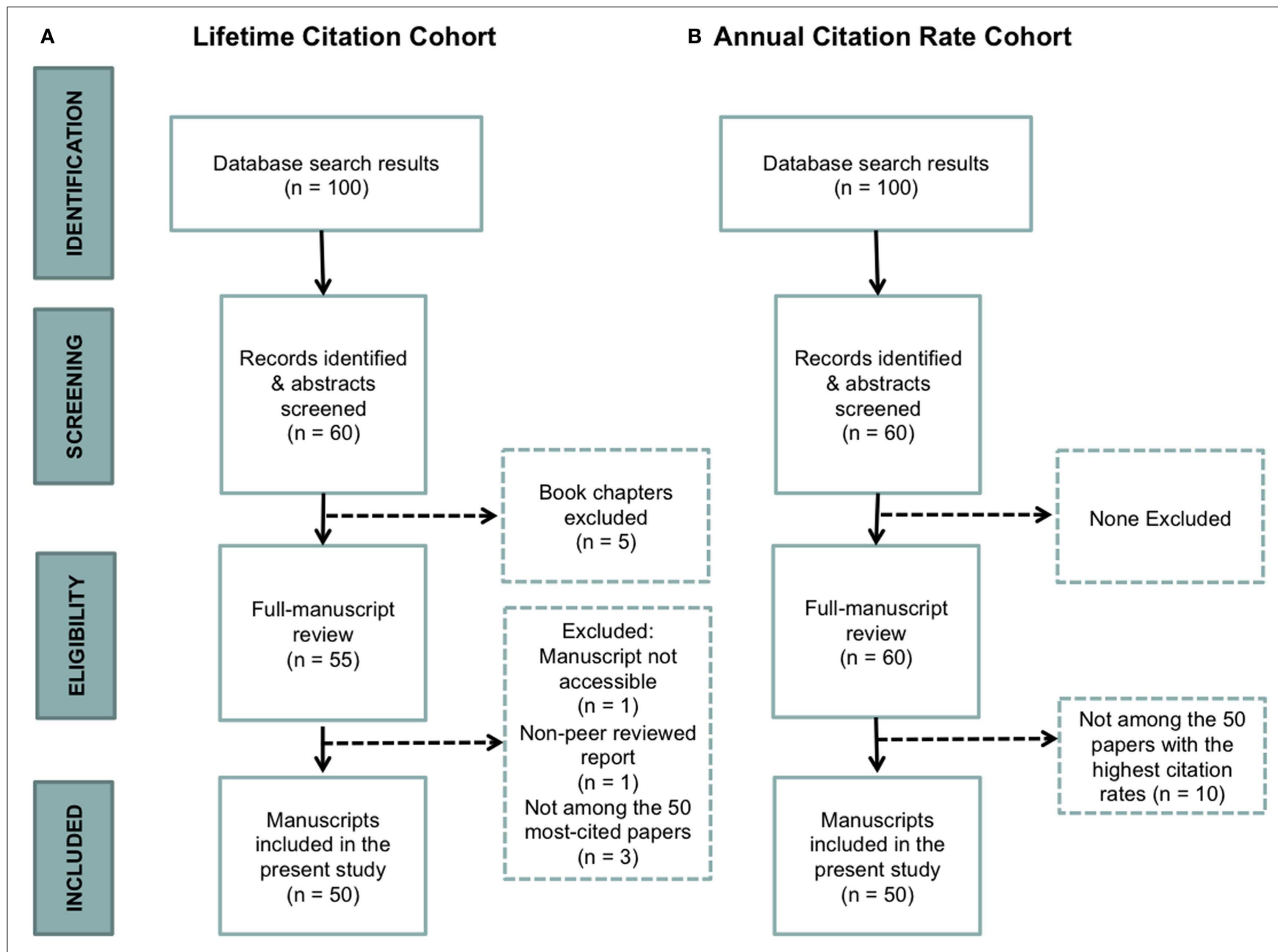

FIGURE 1 | Flow diagram representing the study selection process. (A) Lifetime citation cohort. (B) Annual citation rate cohort.

Severe TBI was studied in four articles (4/10, 40.0\%), mild TBI in three papers $(3 / 10,30.0 \%)$, and two studies $(2 / 10,20.0 \%)$ had a mixed sample with respect to TBI severity. Information on TBI severity was not available for one study $(1 / 10,10.0 \%)$.

Of the 50 articles with the highest annual citation rates, nine (9/50, 18.0\%) focused on pathology/natural history; six of these were common to the 50 top-cited articles in TBI. Relative to the cohort of papers with the most absolute citations, a greater proportion of the citation rate studies were review articles $(4 / 9,44.4 \%)$ and involved human subjects $(7 / 9,77.8 \%)$. A dissection by TBI severity revealed that mild TBI was studied in three papers $(3 / 9$, $33.3 \%)$, severe TBI in another $(1 / 9,11.1 \%)$, while samples with heterogeneous injury severity were studied in three articles (3/9, $33.3 \%)$. TBI severity could not be determined in the remaining papers $(2 / 9,22.2 \%)$.

\section{TREATMENT}

Treatment was the focus of eight of the 50 top-cited articles in TBI $(8 / 50,16.0 \%)$. The majority of these articles $(6 / 8,75.0 \%)$ involved human subjects; the remainder studied pre-clinical treatment options for TBI in animal models $(2 / 8,25.0 \%)$. Most articles studied treatment in the context of severe TBI $(6 / 8,75.0 \%)$, and many treatment articles were randomized control trials (5/8, 62.5\%).

Of the $50 \mathrm{TBI}$ articles with the highest annual citation rates, the subject of $11(11 / 50,22.0 \%)$ was treatment. When compared to the cohort of treatment studies with the most lifetime citations, a similar proportion of these articles involved human subjects $(9 / 11$, $81.8 \%)$ and focused on moderate-to-severe or severe TBI (9/11, $81.8 \%)$. TBI treatment studies with the highest annual citation rates, however, studied interventions, such as administration of corticosteroids $(1 / 11,9.1 \%)$ or progesterone $(1 / 11,9.1 \%)$, which the top-cited treatment articles did not. Relative to papers with the most lifetime citations, a similar percentage of papers in the citation rate cohort $(7 / 11,63.6 \%)$ were randomized controlled trials.

\section{GUIDELINES AND CONSENSUS STATEMENTS}

Six of the 50 top-cited TBI articles $(6 / 50,12.0 \%)$ were guidelines and/or consensus statements. Two-thirds $(4 / 6,66.7 \%)$ of these articles were a product of international collaboration. The 
Table 1 |TBI publications with the most lifetime citations $(n=50)$.

\section{Rank First author Study title}

$1 \quad$ Chestnut, RM

The role of secondary brain injury in determining

outcome from severe head injury

2 Gronwall, DM

Paced auditory serial-addition task: a measure of recovery from concussion

Brines, ML

Erythropoietin crosses the blood-brain barrier to protect against experimental brain injury

$4 \quad$ Faden, $\mathrm{A}$

The role of excitatory amino acids and NMDA receptors in traumatic brain injury

$5 \quad$ Marion, DW

Treatment of traumatic brain injury with moderate hypothermia

$6 \quad$ Clifton, GL

Lack of effect of induction of hypothermia after acute brain injury

$7 \quad$ Hoge, $\mathrm{CW}$

Mild traumatic brain injury in soldiers returning from Iraq

Rimel, RW

ATP mediates rapid microglial response to local brain injury in vivo

Disability caused by minor head injury

10

Adams, JH

$11 \quad$ Muizelaar, JP

12

14 Langlois, JA

15

McCrory, $\mathrm{P}$

16

Marmarou, A

18

Ommaya, AK

19

Adams, JH

in human beings: an analysis of 45 cases

Adverse effects of prolonged hyperventilation in

patients with severe head injury: a randomized

clinical trial

health perspective

The outcome from severe head injury with early

diagnosis and intensive management

injury: a brief overview

3rd International Conference on Concussion in

Sport held in Zurich

computed tomography pathophysiology and biomechanics clinical observations on blunt head injuries

Diffuse axonal injury in head injury: definition,

\section{Year of \\ Number of Annual citation rate Topic/focus \\ publication citations (citations/year)}

1993

1645

78.3

Predictor of

1999

2006 unconsciousness: correlation of experimental and diagnosis, and grading
1977

1485

1318

1300

1215

1182

1156

1081

1010

1982

1991

1977

941

930

2009

907

1991

899

1994

887

1974

outcome

40.1 Assessment

measure

$94.1 \quad$ Treatment

$52.0 \quad$ Treatment

$71.5 \quad$ Treatment

$90.9 \quad$ Treatment

$192.7 \quad$ Predictor of

outcome

$120.1 \quad$ Pathology/natural

history

$31.0 \quad$ Predictor of

outcome

$31.6 \quad$ Pathology/natural

history

Treatment

$42.9 \quad$ Treatment

$64.2 \quad$ Epidemiology

$25.4 \quad$ Treatment

116.3 Epidemiology

181.4 Guidelines and

consensus

statements

$39.1 \quad$ Pathology/natural

history

44.4 Experimental

model of TBI

Experimental model of TBI

1989
32.4
Pathology/natural history 


\section{Table 1 | Continued}

\section{Rank First author \\ Study title}

Cerebral blood flow and metabolism in comatose patients with acute head injury: relationship to intracranial hypertension

21 Mclntosh, TK

Traumatic brain injury in the rat: characterization of a lateral fluid-percussion model

22 Jennett, B

Disability after severe head injury: observations on the use of the Glasgow Outcome Scale

23 Dixon, CE

A fluid-percussion model of experimental brain injury in the rat

$24 \quad$ Miller, JD

Significance of intracranial hypertension in severe head injury

25 Alexander, MP

Mild traumatic brain injury: pathophysiology, natural history, and clinical management

26 Levin, HS Neurobehavioral outcome following minor head injury: a three-center study

27 Katayama, $Y$

Massive increases in extracellular potassium and the indiscriminate release of glutamate following concussive brain injury

28 Levin, HS

The Galveston Orientation and Amnesia Test: a practical scale to assess cognition after head injury

29 Bullock, $\mathrm{R}$

Guidelines for the management of severe head injury

30 Dixon, CE

A controlled cortical impact model of traumatic brain injury in the rat

31 Robertson, $\mathrm{IH}$

Oops!: performance correlates of everyday attentional failures in traumatic brain injured and normal subjects

Cumulative effects associated with recurrent concussion in collegiate football players: The NCAA Concussion Study

33 Bouma, GJ

Cerebral circulation and metabolism after severe traumatic brain injury: the elusive role of ischemia

34 Aubry, $\mathrm{M}$

Summary and agreement statement of The first International Conference on Concussion in Sport, Vienna 2001

Impact of ICP instability and hypertension on outcome in patients with severe head trauma

$36 \quad$ Stiell, IG
The Canadian CT Head Rule for patients with minor head injury

\section{Year of Number of Annual citation rate Topic/focus \\ publication citations \\ (citations/year)}

\begin{tabular}{|c|c|c|c|}
\hline 1984 & 800 & 26.7 & $\begin{array}{l}\text { Predictor of } \\
\text { outcome }\end{array}$ \\
\hline 1989 & 797 & 31.9 & $\begin{array}{l}\text { Predictor of } \\
\text { outcome }\end{array}$ \\
\hline 1981 & 781 & 23.7 & $\begin{array}{l}\text { Predictor of } \\
\text { outcome }\end{array}$ \\
\hline 1987 & 764 & 28.3 & $\begin{array}{l}\text { Predictor of } \\
\text { outcome }\end{array}$ \\
\hline 1977 & 761 & 20.6 & $\begin{array}{l}\text { Predictor of } \\
\text { outcome }\end{array}$ \\
\hline 1995 & 759 & 40.0 & $\begin{array}{l}\text { Pathology/natural } \\
\text { history }\end{array}$ \\
\hline 1987 & 756 & 28.0 & $\begin{array}{l}\text { Predictor of } \\
\text { outcome }\end{array}$ \\
\hline 1990 & 754 & 31.4 & $\begin{array}{l}\text { Pathology/natural } \\
\text { history }\end{array}$ \\
\hline 1979 & 752 & 21.5 & $\begin{array}{l}\text { Assessment } \\
\text { measure }\end{array}$ \\
\hline 1996 & 740 & 41.1 & $\begin{array}{l}\text { Guidelines and } \\
\text { consensus } \\
\text { statements }\end{array}$ \\
\hline 1991 & 737 & 32.0 & $\begin{array}{l}\text { Predictor of } \\
\text { outcome }\end{array}$ \\
\hline 1997 & 714 & 42.0 & $\begin{array}{l}\text { Assessment } \\
\text { measure }\end{array}$ \\
\hline 2003 & 670 & 60.9 & Epidemiology \\
\hline 1991 & 665 & 28.9 & $\begin{array}{l}\text { Predictor of } \\
\text { outcome }\end{array}$ \\
\hline 2002 & 640 & 53.3 & $\begin{array}{l}\text { Guidelines and } \\
\text { consensus } \\
\text { statements }\end{array}$ \\
\hline 1991 & 640 & 27.8 & $\begin{array}{l}\text { Predictor of } \\
\text { outcome }\end{array}$ \\
\hline 2001 & 637 & 49.0 & $\begin{array}{l}\text { Guidelines and } \\
\text { consensus } \\
\text { statements }\end{array}$ \\
\hline
\end{tabular}

(Continued) 
Table 1 | Continued

\begin{tabular}{|c|c|c|c|c|c|c|}
\hline Rank & First author & Study title & $\begin{array}{l}\text { Year of } \\
\text { publication }\end{array}$ & $\begin{array}{l}\text { Number of } \\
\text { citations }\end{array}$ & $\begin{array}{l}\text { Annual citation rate } \\
\text { (citations/year) }\end{array}$ & Topic/focus \\
\hline 37 & McCrory, P & $\begin{array}{l}\text { Summary and agreement statement of The 2nd } \\
\text { International Conference on Concussion in Sport, } \\
\text { Prague } 2004\end{array}$ & 2005 & 629 & 69.9 & $\begin{array}{l}\text { Guidelines and } \\
\text { consensus } \\
\text { statements }\end{array}$ \\
\hline 38 & Gronwall, DM & $\begin{array}{l}\text { Delayed recovery of intellectual function after } \\
\text { minor head injury }\end{array}$ & 1974 & 625 & 15.8 & $\begin{array}{l}\text { Predictor of } \\
\text { outcome }\end{array}$ \\
\hline 39 & Miller, JD & $\begin{array}{l}\text { Further experience in the management of severe } \\
\text { head injury }\end{array}$ & 1981 & 624 & 18.9 & $\begin{array}{l}\text { Predictor of } \\
\text { outcome }\end{array}$ \\
\hline 40 & Strich, SJ & $\begin{array}{l}\text { Diffuse degeneration of the cerebral white matter } \\
\text { in severe dementia following head injury }\end{array}$ & 1956 & 606 & 10.5 & $\begin{array}{l}\text { Pathology/natural } \\
\text { history }\end{array}$ \\
\hline 41 & Yakolev, AG & $\begin{array}{l}\text { Activation of CPP32-like caspases contributes to } \\
\text { neuronal apoptosis and neurological dysfunction } \\
\text { after traumatic brain injury }\end{array}$ & 1997 & 603 & 35.5 & $\begin{array}{l}\text { Pathology/natural } \\
\text { history }\end{array}$ \\
\hline 42 & Jennett, B & $\begin{array}{l}\text { Predicting outcome in individual patients after } \\
\text { severe head injury }\end{array}$ & 1976 & 600 & 15.8 & $\begin{array}{l}\text { Predictor of } \\
\text { outcome }\end{array}$ \\
\hline 43 & Collins, MW & $\begin{array}{l}\text { Relationship between concussion and } \\
\text { neuropsychological performance in college football } \\
\text { players }\end{array}$ & 1999 & 594 & 39.6 & $\begin{array}{l}\text { Predictor of } \\
\text { outcome }\end{array}$ \\
\hline 44 & Clifton, GL & $\begin{array}{l}\text { A phase II study of moderate hypothermia in } \\
\text { severe brain injury }\end{array}$ & 1993 & 591 & 28.1 & Treatment \\
\hline 45 & Brooks, N & $\begin{array}{l}\text { The 5-year outcome of severe blunt head injury: a } \\
\text { relative's view }\end{array}$ & 1986 & 589 & 21.0 & $\begin{array}{l}\text { Pathology/natural } \\
\text { history }\end{array}$ \\
\hline 46 & Denny-Brown, D & Experimental cerebral concussion & 1941 & 588 & 8.1 & $\begin{array}{l}\text { Experimental } \\
\text { model of TBI }\end{array}$ \\
\hline 47 & Shiozaki, T & $\begin{array}{l}\text { Effect of mild hypothermia on uncontrollable } \\
\text { intracranial hypertension after severe head injury }\end{array}$ & 1993 & 585 & 27.9 & Treatment \\
\hline 48 & Narayan, RK & Clinical trials in head injury & 2002 & 580 & 48.3 & $\begin{array}{l}\text { Guidelines and } \\
\text { consensus } \\
\text { statements }\end{array}$ \\
\hline 49 & Teasdale, GM & $\begin{array}{l}\text { Association of apolipoprotein E polymorphism with } \\
\text { outcome after head injury }\end{array}$ & 1997 & 574 & 33.6 & $\begin{array}{l}\text { Predictor of } \\
\text { outcome }\end{array}$ \\
\hline 50 & Rink, A & $\begin{array}{l}\text { Evidence of apoptotic cell death after experimental } \\
\text { traumatic brain injury in the rat }\end{array}$ & 1995 & 574 & 30.1 & $\begin{array}{l}\text { Pathology/natural } \\
\text { history }\end{array}$ \\
\hline
\end{tabular}

majority of these articles $(4 / 6,66.7 \%)$ pertained to mild TBI, including three $(3 / 6,50.0 \%)$ focusing exclusively on sports-related concussion. One consensus statement $(1 / 6,16.7 \%)$ concerned severe TBI, and another $(1 / 6,16.7 \%)$ provided guidelines on how to manage TBI of all severities.

Of the $50 \mathrm{TBI}$ articles with the highest annual citation rates, nine $(9 / 50,18.0 \%)$ were guidelines and consensus statements; six of these were common to the 50 most-cited articles in TBI. An analysis by TBI severity revealed that mild TBI was the focus of six articles $(6 / 9,66.7 \%)$, three of which $(3 / 6,50.0 \%)$ were exclusively focused on concussion. One consensus statement $(1 / 9,11.1 \%)$ discussed pediatric head injuries specifically.

\section{EPIDEMIOLOGY}

The 50 most-cited articles in TBI included three (3/50, 6.0\%) epidemiological studies. One of these articles $(1 / 3,33.3 \%)$ studied the full spectrum of brain injury (e.g., mild-to-severe), while another $(1 / 3,33.3 \%)$ provided an epidemiological context to mild TBI only. The latter study was specific to TBI in sport.

In contrast, of the $50 \mathrm{TBI}$ articles with the highest annual citation rates, $10(10 / 50,20.0 \%)$ were epidemiological. Half $(5 / 10,50.0 \%)$ of these articles studied the full spectrum of TBI severity, with one study $(1 / 10,10.0 \%)$ focusing exclusively on mild TBI. The single article studying the epidemiology of mild TBI did so in the context of sports. Another article (1/10, 
Table 2 |TBI publications with the highest annual citation rates $(\boldsymbol{n}=\mathbf{5 0})$.

\begin{tabular}{|c|c|c|c|c|c|c|}
\hline Rank & First author & Study title & $\begin{array}{l}\text { Year of } \\
\text { publication }\end{array}$ & $\begin{array}{l}\text { Number of } \\
\text { citations }\end{array}$ & $\begin{array}{l}\text { Annual citation rate } \\
\text { (citations/year) }\end{array}$ & Topic/focus \\
\hline 1 & Hoge, CW & $\begin{array}{l}\text { Mild traumatic brain injury in soldiers returning } \\
\text { from Iraq }\end{array}$ & 2008 & 1156 & 192.7 & $\begin{array}{l}\text { Predictor of } \\
\text { outcome }\end{array}$ \\
\hline 2 & McCrory, P & $\begin{array}{l}\text { Consensus statement on concussion in sport: The } \\
\text { 3rd International Conference on Concussion in } \\
\text { Sport held in Zurich }\end{array}$ & 2009 & 907 & 181.4 & $\begin{array}{l}\text { Guidelines and } \\
\text { consensus } \\
\text { statements }\end{array}$ \\
\hline 3 & McCrory, P & $\begin{array}{l}\text { Consensus statement on concussion in sport: The } \\
\text { 4th International Conference on Concussion in } \\
\text { Sport held in Zurich, November, } 2012\end{array}$ & 2013 & 169 & 169.0 & $\begin{array}{l}\text { Guidelines and } \\
\text { consensus } \\
\text { statements }\end{array}$ \\
\hline 4 & Davalos, D & $\begin{array}{l}\text { ATP mediates rapid microglial response to local } \\
\text { brain injury in vivo }\end{array}$ & 2005 & 1081 & 120.1 & $\begin{array}{l}\text { Pathology/natural } \\
\text { history }\end{array}$ \\
\hline 7 & McKee, AC & $\begin{array}{l}\text { Chronic traumatic encephalopathy in athletes: } \\
\text { progressive tauopathy following repetitive head } \\
\text { injury }\end{array}$ & 2009 & 510 & 102.0 & $\begin{array}{l}\text { Predictor of } \\
\text { outcome }\end{array}$ \\
\hline 8 & Brines, ML & $\begin{array}{l}\text { Erythropoietin crosses the blood-brain barrier to } \\
\text { protect against experimental brain injury }\end{array}$ & 2000 & 1318 & 94.1 & Treatment \\
\hline 9 & Clifton, GL & $\begin{array}{l}\text { Lack of effect of induction of hypothermia after } \\
\text { acute brain injury }\end{array}$ & 2001 & 1182 & 90.9 & Treatment \\
\hline 13 & McCrory, P & $\begin{array}{l}\text { Summary and agreement statement of The } 2 \text { nd } \\
\text { International Conference on Concussion in Sport, } \\
\text { Prague } 2004\end{array}$ & 2005 & 629 & 69.9 & $\begin{array}{l}\text { Guidelines and } \\
\text { consensus } \\
\text { statements }\end{array}$ \\
\hline 14 & Thurman, DJ & $\begin{array}{l}\text { Traumatic brain injury in the United Stats: a public } \\
\text { health perspective }\end{array}$ & 1999 & 963 & 64.2 & Epidemiology \\
\hline 15 & Warden, D & Military TBI during the Iraq and Afghanistan wars & 2006 & 490 & 61.3 & Epidemiology \\
\hline 16 & Guskiewicz, KM & $\begin{array}{l}\text { Cumulative effects associated with recurrent } \\
\text { concussion in collegiate football players: The NCAA } \\
\text { Concussion Study }\end{array}$ & 2003 & 670 & 60.9 & Epidemiology \\
\hline 17 & Kraus, MF & $\begin{array}{l}\text { White matter integrity and cognition in chronic } \\
\text { traumatic brain injury: a diffusion tensor imaging } \\
\text { study }\end{array}$ & 2007 & 426 & 60.9 & $\begin{array}{l}\text { Pathology/natural } \\
\text { history }\end{array}$ \\
\hline 18 & Tagliaferri, F & $\begin{array}{l}\text { A systematic review of brain injury epidemiology in } \\
\text { Europe }\end{array}$ & 2006 & 485 & 60.6 & Epidemiology \\
\hline
\end{tabular}


Table 2 | Continued

\begin{tabular}{|c|c|c|c|c|c|c|}
\hline Rank & First author & Study title & $\begin{array}{l}\text { Year of } \\
\text { publication }\end{array}$ & $\begin{array}{l}\text { Number of } \\
\text { citations }\end{array}$ & $\begin{array}{l}\text { Annual citation rate } \\
\text { (citations/year) }\end{array}$ & Topic/focus \\
\hline 19 & Kuppermann, N & $\begin{array}{l}\text { Identification of children at very low risk of clinically } \\
\text { important brain injuries after head trauma: a } \\
\text { prospective cohort study }\end{array}$ & 2009 & 303 & 60.4 & $\begin{array}{l}\text { Predictor of } \\
\text { outcome }\end{array}$ \\
\hline 20 & Okie, S & Traumatic brain injury in the war zone & 2005 & 512 & 56.9 & $\begin{array}{l}\text { Predictor of } \\
\text { outcome }\end{array}$ \\
\hline 21 & Aubry, M & $\begin{array}{l}\text { Summary and agreement statement of The first } \\
\text { International Conference on Concussion in Sport, } \\
\text { Vienna } 2001\end{array}$ & 2002 & 640 & 53.3 & $\begin{array}{l}\text { Guidelines and } \\
\text { consensus } \\
\text { statements }\end{array}$ \\
\hline 22 & Saatman, KE & $\begin{array}{l}\text { Classification of traumatic brain injury for targeted } \\
\text { therapies }\end{array}$ & 2008 & 320 & 53.3 & $\begin{array}{l}\text { Pathology/natural } \\
\text { history }\end{array}$ \\
\hline 23 & Roberts & $\begin{array}{l}\text { Effect of intravenous corticosteroids on death } \\
\text { within } 14 \text { days in 10,008 adults with clinically } \\
\text { significant head injury (MRC CRASH trial): } \\
\text { randomized placebo-controlled trial }\end{array}$ & 2004 & 533 & 53.3 & Treatment \\
\hline 24 & Schiff, ND & $\begin{array}{l}\text { Behavioral improvements with thalamic stimulation } \\
\text { after severe traumatic brain injury }\end{array}$ & 2007 & 371 & 53.0 & Treatment \\
\hline 25 & Faden, A & $\begin{array}{l}\text { The role of excitatory amino acids and NMDA } \\
\text { receptors in traumatic brain injury }\end{array}$ & 1989 & 1300 & 52.0 & Treatment \\
\hline 26 & Carroll, L & $\begin{array}{l}\text { Prognosis for mild traumatic brain injury: results of } \\
\text { the WHO collaborating center task force on mild } \\
\text { traumatic brain injury }\end{array}$ & 2004 & 519 & 51.9 & $\begin{array}{l}\text { Pathology/natural } \\
\text { history }\end{array}$ \\
\hline 27 & McCrea, M & $\begin{array}{l}\text { Acute effects and recovery time following } \\
\text { concussion in collegiate football players: The NCAA } \\
\text { Concussion Study }\end{array}$ & 2003 & 566 & 51.5 & $\begin{array}{l}\text { Pathology/natural } \\
\text { history }\end{array}$ \\
\hline 28 & Aarabi, B & $\begin{array}{l}\text { Outcome following decompressive craniectomy for } \\
\text { malignant swelling due to severe head injury }\end{array}$ & 2006 & 410 & 51.3 & Treatment \\
\hline 29 & Schneiderman, Al & $\begin{array}{l}\text { Understanding sequelae of injury mechanisms and } \\
\text { mild traumatic brain injury incurred during the } \\
\text { conflicts in Iraq and Afghanistan: persistent } \\
\text { post-concussive symptoms and post-traumatic } \\
\text { stress disorder }\end{array}$ & 2008 & 307 & 51.2 & Epidemiology \\
\hline 30 & Werner, C & Pathophysiology of traumatic brain injury & 2007 & 348 & 49.7 & $\begin{array}{l}\text { Pathology/natural } \\
\text { history }\end{array}$ \\
\hline 31 & Stiell, IG & $\begin{array}{l}\text { The Canadian CT Head Rule for patients with minor } \\
\text { head injury }\end{array}$ & 2001 & 637 & 49.0 & $\begin{array}{l}\text { Guidelines and } \\
\text { consensus } \\
\text { statements }\end{array}$ \\
\hline 32 & Bullock, MR & $\begin{array}{l}\text { Guidelines for the management of severe } \\
\text { traumatic brain injury. Editor's commentary }\end{array}$ & 2007 & 343 & 49.0 & $\begin{array}{l}\text { Guidelines and } \\
\text { consensus } \\
\text { statements }\end{array}$ \\
\hline 33 & Bruns, J & The epidemiology of traumatic brain injury: a review & 2003 & 536 & 48.7 & Epidemiology \\
\hline 34 & Narayan, RK & Clinical trials in head injury & 2002 & 580 & 48.3 & $\begin{array}{l}\text { Guidelines and } \\
\text { consensus } \\
\text { statements }\end{array}$ \\
\hline
\end{tabular}




\section{Table 2 | Continued}

\begin{tabular}{|c|c|c|c|c|c|c|}
\hline Rank & First author & Study title & $\begin{array}{l}\text { Year of } \\
\text { publication }\end{array}$ & $\begin{array}{l}\text { Number of } \\
\text { citations }\end{array}$ & $\begin{array}{l}\text { Annual citation rate } \\
\text { (citations/year) }\end{array}$ & Topic/focus \\
\hline 35 & Hutchison, JS & $\begin{array}{l}\text { Hypothermia therapy after traumatic brain injury in } \\
\text { children }\end{array}$ & 2008 & 287 & 47.7 & Treatment \\
\hline 36 & Halstead, ME & $\begin{array}{l}\text { Sport-related concussion in children and } \\
\text { adolescents }\end{array}$ & 2010 & 190 & 47.5 & $\begin{array}{l}\text { Guidelines and } \\
\text { consensus } \\
\text { statements }\end{array}$ \\
\hline 37 & $\begin{array}{l}\text { MRCCT } \\
\text { Collaborators }\end{array}$ & $\begin{array}{l}\text { Predicting outcome after traumatic brain injury: } \\
\text { practical prognostic models based on large cohort } \\
\text { of international patients }\end{array}$ & 2008 & 284 & 47.3 & $\begin{array}{l}\text { Predictor of } \\
\text { outcome }\end{array}$ \\
\hline 38 & Wright, DW & $\begin{array}{l}\text { ProTECT: a randomized clinical trial of progesterone } \\
\text { for acute traumatic brain injury }\end{array}$ & 2007 & 323 & 46.1 & Treatment \\
\hline 40 & Guskiewicz, KM & $\begin{array}{l}\text { Association between recurrent concussion and } \\
\text { late-life cognitive impairment in retired professional } \\
\text { football players }\end{array}$ & 2005 & 402 & 44.7 & $\begin{array}{l}\text { Predictor of } \\
\text { outcome }\end{array}$ \\
\hline 41 & Marmarou, A & $\begin{array}{l}\text { A new model of diffuse brain injury in rats: part 1: } \\
\text { pathophysiology and biomechanics }\end{array}$ & 1994 & 887 & 44.4 & $\begin{array}{l}\text { Experimental } \\
\text { model of TBI }\end{array}$ \\
\hline 42 & Muizelaar, JP & $\begin{array}{l}\text { Adverse effects of prolonged hyperventilation in } \\
\text { patients with severe head injury: a randomized } \\
\text { clinical trial }\end{array}$ & 1991 & 987 & 42.9 & Treatment \\
\hline 43 & Robertson, IH & $\begin{array}{l}\text { Oops!: performance correlates of everyday } \\
\text { attentional failures in traumatic brain injured and } \\
\text { normal subjects }\end{array}$ & 1997 & 714 & 42.0 & $\begin{array}{l}\text { Assessment } \\
\text { measure }\end{array}$ \\
\hline 45 & Panikashvili, D & $\begin{array}{l}\text { An endogenous cannabinoid ( } 2-A G) \text { is } \\
\text { neuroprotective after brain injury }\end{array}$ & 2001 & 536 & 41.2 & $\begin{array}{l}\text { Pathology/natural } \\
\text { history }\end{array}$ \\
\hline 46 & Bullock, R & $\begin{array}{l}\text { Guidelines for the management of severe head } \\
\text { injury }\end{array}$ & 1996 & 740 & 41.1 & $\begin{array}{l}\text { Guidelines and } \\
\text { consensus } \\
\text { statements }\end{array}$ \\
\hline 47 & Gronwall, DM & $\begin{array}{l}\text { Paced auditory serial-addition task: a measure of } \\
\text { recovery from concussion }\end{array}$ & 1977 & 1485 & 40.1 & $\begin{array}{l}\text { Assessment } \\
\text { measure }\end{array}$ \\
\hline 48 & Alexander, MP & $\begin{array}{l}\text { Mild traumatic brain injury: pathophysiology, natural } \\
\text { history, and clinical management }\end{array}$ & 1995 & 759 & 40.0 & $\begin{array}{l}\text { Pathology/natural } \\
\text { history }\end{array}$ \\
\hline 49 & Collins, MW & $\begin{array}{l}\text { Relationship between concussion and } \\
\text { neuropsychological performance in college football } \\
\text { players }\end{array}$ & 1999 & 594 & 39.6 & $\begin{array}{l}\text { Predictor of } \\
\text { outcome }\end{array}$ \\
\hline 50 & Marshall, LF & $\begin{array}{l}\text { A new classification of head injury based on } \\
\text { computed tomography }\end{array}$ & 1991 & 899 & 39.1 & $\begin{array}{l}\text { Pathology/natural } \\
\text { history }\end{array}$ \\
\hline
\end{tabular}




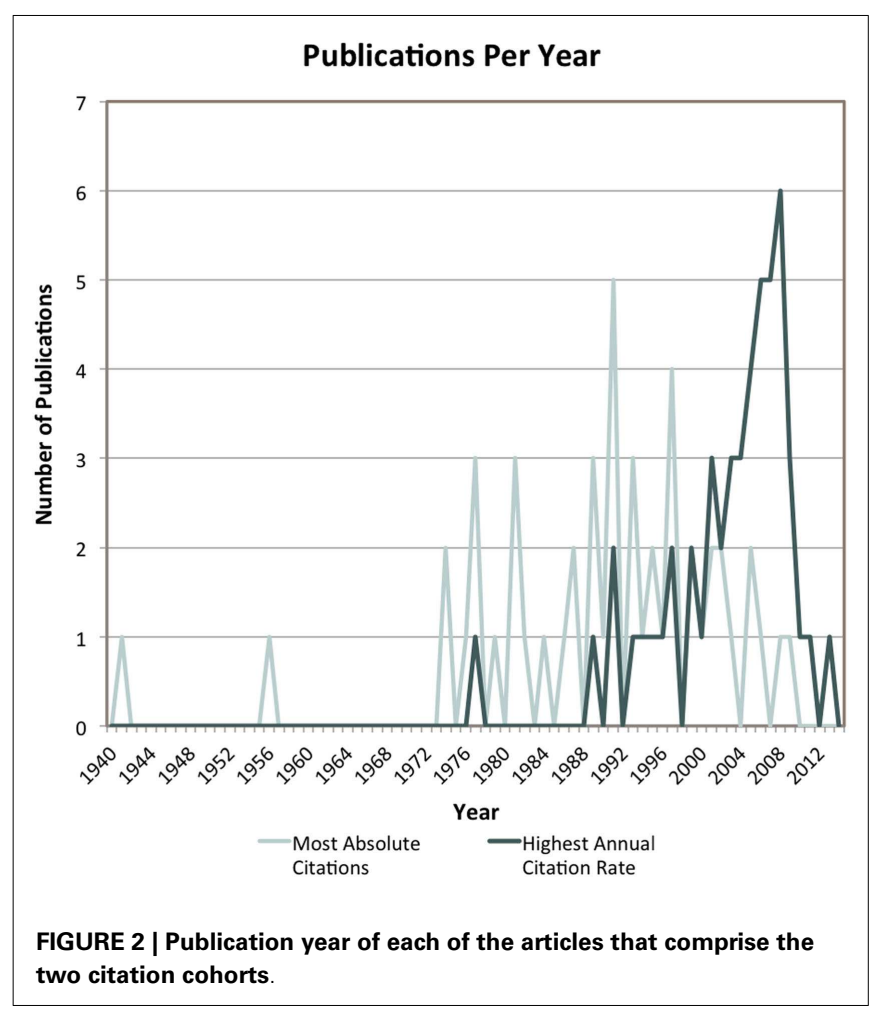

$10.0 \%$ ) investigated the epidemiology of all TBI severities in war veterans.

\section{ASSESSMENT MEASURES}

Of the 50 top-cited articles in TBI, three $(3 / 50,6.0 \%)$ primarily focused on assessment measures. All three studies (3/3, 100.0\%) were prospective cohort investigations of cognitive assessment measures for information processing speed, sustained attention, or post-trauma orientation and amnesia. Two of these articles $(2 / 3$, $66.7 \%$ ) focused on mild TBI and the third (1/3, 33.3\%) explored assessment measures for TBI of any severity. The two studies specific to mild TBI in the most lifetime citation cohort were also among the 50 articles with the highest annual citation rates.

\section{EXPERIMENTAL MODEL OF TBI}

Three papers $(3 / 50,6.0 \%)$ describing an experimental model of TBI (e.g., fluid-percussion models) were identified in the cohort of 50 most-cited TBI articles; one $(1 / 3,33.3 \%)$ of these was common to the citation rate cohort. All three articles were animal studies. One study $(1 / 3,33.3 \%)$ developed a model to explore mild TBI, whereas the others $(2 / 3,66.7 \%)$, which were also common to the citation rate cohort, centered on a model that permitted investigation of mild-to-severe TBI in animals.

\section{DISCUSSION}

In comparing TBI papers with the most lifetime citations to those with the highest annual citation rates, it is possible to gage, respectively, which papers have had the greatest influence in TBI, and which articles are currently discussed, referenced, and shaping the
Table 3 | Characterization of the two citation cohorts

\begin{tabular}{|c|c|c|c|}
\hline & & $\begin{array}{l}\text { TBI publications } \\
\text { with the } \\
\text { most lifetime } \\
\text { citations: } n(\%)\end{array}$ & $\begin{array}{l}\text { TBI publications } \\
\text { with the } \\
\text { highest annual } \\
\text { citation } \\
\text { rates: } n(\%)\end{array}$ \\
\hline \multirow[t]{7}{*}{ Severity } & Mild & $15(30.0)$ & $18(36.0)$ \\
\hline & Mild-to-moderate & $1(2.0)$ & $0(0.0)$ \\
\hline & Mild-to-severe & $9(18.0)$ & $14(28.0)$ \\
\hline & Moderate & $0(0.0)$ & $0(0.0)$ \\
\hline & $\begin{array}{l}\text { Moderate-to- } \\
\text { severe }\end{array}$ & $2(4.0)$ & $3(6.0)$ \\
\hline & Severe & $19(38.0)$ & $11(22.0)$ \\
\hline & Unspecified & $4(8.0)$ & $4(8.0)$ \\
\hline \multirow[t]{5}{*}{ Sample } & Animal & $12(24.0)$ & $5(10.0)$ \\
\hline & Human & $38(76.0)$ & $45(90.0)$ \\
\hline & Pediatric & $3(7.9)$ & $4(8.9)$ \\
\hline & Sport & $9(23.7)$ & $9(20.0)$ \\
\hline & Veteran & $3(7.9)$ & $4(8.9)$ \\
\hline \multirow[t]{10}{*}{ Design } & Case-series & $3(6.0)$ & $1(2.0)$ \\
\hline & Commentary & $0(0.0)$ & $1(2.0)$ \\
\hline & $\begin{array}{l}\text { Consensus state- } \\
\text { ment/guidelines }\end{array}$ & $4(8.0)$ & $6(12.0)$ \\
\hline & Cross-sectional & $0(0.0)$ & $2(4.0)$ \\
\hline & $\begin{array}{l}\text { Prospective cohort; } \\
\text { uncontrolled }\end{array}$ & $14(28.0)$ & $8(16.0)$ \\
\hline & $\begin{array}{l}\text { Prospective cohort; } \\
\text { controlled }\end{array}$ & $6(12.0)$ & $4(8.0)$ \\
\hline & $\begin{array}{l}\text { Randomized } \\
\text { control trial }\end{array}$ & $5(10.0)$ & $7(14.0)$ \\
\hline & $\begin{array}{l}\text { Retrospective } \\
\text { cohort }\end{array}$ & $2(4.0)$ & $2(4.0)$ \\
\hline & Review & $6(12.0)$ & $14(28.0)$ \\
\hline & Unspecified & $10(20.0)$ & $5(10.0)$ \\
\hline \multirow{10}{*}{$\begin{array}{l}\text { Country of } \\
\text { correspon- } \\
\text { dence }\end{array}$} & Australia & $2(4.0)$ & $4(8.0)$ \\
\hline & Belgium & $0(0.0)$ & $1(2.0)$ \\
\hline & Canada & $2(4.0)$ & $5(10.0)$ \\
\hline & Germany & $0(0.0)$ & $1(2.0)$ \\
\hline & Israel & $0(0.0)$ & $1(2.0)$ \\
\hline & Japan & $1(2.0)$ & $0(0.0)$ \\
\hline & New Zealand & $2(4.0)$ & $1(2.0)$ \\
\hline & United Kingdom & $9(18.0)$ & $2(4.0)$ \\
\hline & $\begin{array}{l}\text { United States of } \\
\text { America }\end{array}$ & $34(68.0)$ & $33(66.0)$ \\
\hline & Multi-national & $0(0.0)$ & $2(4.0)$ \\
\hline $\begin{array}{l}\text { Product of } \\
\text { international } \\
\text { collaboration }\end{array}$ & & $8(16.0)$ & $14(28.0)$ \\
\hline
\end{tabular}

Average

number of

$6.5 \pm 6.2 \quad 10.3 \pm 10.6$ 
Table 4 | Categorical dissection of publications in both citation cohorts.

\begin{tabular}{|c|c|c|}
\hline & $\begin{array}{l}\text { Publications } \\
\text { with the most } \\
\text { lifetime } \\
\text { citations: } n(\%)\end{array}$ & $\begin{array}{l}\text { Publications } \\
\text { with the } \\
\text { highest annual } \\
\text { citation rates: } n(\%)\end{array}$ \\
\hline Predictor of outcome & $17(34.0)$ & $8(16.0)$ \\
\hline Cognitive & $3(17.6)$ & $2(25.0)$ \\
\hline Gross & $5(29.4)$ & $3(37.5)$ \\
\hline Mortality & $5(29.4)$ & $1(12.5)$ \\
\hline Neurological & $4(23.5)$ & $2(25.0)$ \\
\hline Pathology/natural history & $10(20.0)$ & $9(18.0)$ \\
\hline Gross & $2(20.0)$ & $1(11.1)$ \\
\hline Functional & $1(10.0)$ & $3(33.3)$ \\
\hline Histological & $4(40.0)$ & $2(22.2)$ \\
\hline Physiological & $3(30.0)$ & $3(33.3)$ \\
\hline Treatment & $8(16.0)$ & $11(22.0)$ \\
\hline Pharmacological intervention & $2(25.0)$ & $4(36.4)$ \\
\hline Hyperventilation & $1(12.5)$ & $1(9.1)$ \\
\hline Hypothermia & $4(50.0)$ & $3(27.3)$ \\
\hline Neurosurgical & $1(12.5)$ & $3(27.3)$ \\
\hline $\begin{array}{l}\text { Guidelines and consensus } \\
\text { statements }\end{array}$ & $6(12.0)$ & $9(18.0)$ \\
\hline Epidemiology & $3(6.0)$ & $10(20.0)$ \\
\hline Assessment measure & $3(6.0)$ & $2(4.0)$ \\
\hline Experimental model of TBI & $3(6.0)$ & $1(2.0)$ \\
\hline
\end{tabular}

Note: The "Predictor of outcome" category was specific to articles investigating the relationship between a variable and outcome at a later time point, whereas the "Pathology/natural history" category was appropriated to studies investigating the natural course and manifestations of TBI.

field. Below, we provide a general discussion of our findings, which is followed by a category-specific commentary where appropriate.

Our data show that studies on mild TBI are currently accumulating the most citations per year, although studies on severe TBI have been more widely cited (Table 3 ). This suggests that mild TBI is presently a central point of discussion in the field of brain injury, perhaps because mild TBI is the most prevalent form of TBI (Faul et al., 2010) and has, as a result, the most scope for preventive research; is of social and public concern, given its incidence in sports and the military (Langlois et al., 2006; Chen and D'Esposito, 2010; Cusimano et al., 2013); is a risk factor for other disorders (e.g., depression and anxiety) and neurodegenerative diseases such as chronic traumatic encephalopathy and Alzheimer's disease (Plassman et al., 2000; McCauley et al., 2001; Holsinger et al., 2002; Fleminger et al., 2003; Seel et al., 2003; Gavett et al., 2010, 2011; Masel and DeWitt, 2010; Stern et al., 2011), and thereby draws interest and citations across a number of neuroscience disciplines; may now be extensively researched to overcome some of the documented shortcomings of former studies on mild TBI (Carroll et al., 2004). Furthermore, relative to papers with the most lifetime citations, a greater proportion of articles that are accumulating the most citations annually involved human subjects (Table 3). This suggests a shifted focus from animal to clinical research, and perhaps a piqued interest in understanding, in particular, human brain and behavior after TBI. In addition, studies with the highest annual citation rates involved, on average, more routine international collaboration than papers with the most lifetime citations (Table 3). Increased international collaboration may ultimately benefit our understanding of TBI by facilitating comparative effectiveness treatment research, the development of brain injury biomarkers, and an improved ability to predict outcome following TBI (Tosetti et al., 2013). Moreover, the articles that comprised the citation rate cohort were, on average, authored by a greater number of individuals (Table 3). As larger groups conducted these studies, they may, therefore, benefit from greater scientific diversity and perspective.

Speculating on future trends in TBI research would suggest a sustained focus on treatment of TBI, given that patients continue to experience persistent cognitive and emotional impairment more than 5 years following mild trauma (Konrad et al., 2011). It may also be reasonable to expect an increase in research activity on assessment measures for TBI, given the push to be able to more reliability and immediately identify brain injury in the context of sports (Charleswell et al., 2014). As TBI research evolves and new knowledge is assimilated into current understanding and practice, is also likely that there will be greater research activity surrounding guidelines and consensus statements.

We would like to note that increased research activity in one subfield may influence activity in another. For example, a shifted research focus on treatment of TBI may engender downstream epidemiological research designed to assess treatment effects at the population level. Likewise, an increased focus on treatment may result in updated guidelines or consensus statements. Below, however, only category-specific findings are discussed.

\section{PREDICTOR OF OUTCOME}

Over a third of the 50 top-cited articles in TBI studied predictors of outcome, indicating that this subfield of brain injury has been extensively researched. Moreover, eight of the 50 articles with the highest yearly citation rates focused on predictors of outcome, and half of these were also among the 50 top-cited articles in TBI. This indicates that novel research on predictors of outcome - not only former, seminal work in this subfield - continues to be discussed and cited widely. A sustained research effort into predictors of outcome is required to inform clinicians as to which patients are at greatest risk of poor long-term outcome, and, therefore, should be targeted for a particular management strategy or therapeutic intervention. Moreover, articles with the highest annual citation rates most often predicted cognitive, gross, and neurological outcomes following TBI, and not mortality, like many of 50 most-cited publications in TBI. A reduced emphasis on predicting mortality following brain injury may be commensurate with our improved ability to save the lives of TBI patients through primary prevention (e.g., seatbelt use) and case management (Stiefel et al., 2005).

\section{PATHOLOGY/NATURAL HISTORY}

Investigations into pathological outcome and natural history following TBI are important for understanding the recovery 
and progression of brain injury. The most highly cited pathology/natural history studies examined histological outcomes and physiological response to trauma; however, the articles with the highest citation rates more often investigated functional outcomes post-TBI. This suggests a shifted focus, wherein patient-centered functional outcomes have become a more central point of research. This echoes the growing appreciation for the functional sequelae of brain injuries (Morton and Wehman, 1995), and identification of barriers to functional recovery that prevent restoration of pre-morbid abilities (Powell et al., 2001).

\section{TREATMENT}

Two treatment articles with the highest annual citation rates were not common to the 50 most-cited articles in TBI. This suggests that some TBI treatment articles, despite not yet accumulating the requisite number of citations to be among the most-cited articles in TBI, are currently being regularly discussed and referenced within the scientific community. Discussion of and research into new treatment options for TBI is necessary given the limited efficacy of many currently available brain injury treatment and management options (Maas et al., 2012; Ponsford et al., 2014a,b; Velikonja et al., 2014), despite our increased pathophysiological understanding of TBI (Zitnay et al., 2008).

\section{GUIDELINES AND CONSENSUS STATEMENTS}

The greatest number of guidelines and consensus statements specific to TBI were identified in the citation rate cohort, indicating a current increase in scientific discussion on this topic. However, it should be noted that recent research indicates that, on average, TBI guidelines are based on low levels of evidence (Maas et al., 2012). This highlights the need to design and conduct studies on TBI that can provide high-level evidence that will advance the science and inform TBI guidelines of a higher standard. Nonetheless, the guidelines and consensus statements that are currently being referenced are particular to mild TBI and concussion. The observed increase in referencing of concussion and mild TBI guidelines echoes the growing interest and research activity in this field (Table 3).

\section{EPIDEMIOLOGY}

We observed that a greater proportion of the citation rate cohort comprised epidemiological studies than the absolute citation cohort. This suggests that our epidemiological knowledge of TBI is continually developing, re-contextualizing our understanding of the prevalence of TBI and the associated scope for prevention, characteristics of vulnerable populations, and how to distribute resources to manage TBI. Continued epidemiological research into TBI is required given that the incidence of this injury is changing (Maas et al., 2012). This is largely due to increased availability and use of motor vehicles in developing nations, and, therefore, greater potential for TBIs to be caused by motor vehicle collisions in these countries (Maas et al., 2008). In developed nations, moreover, rates of TBI are also on the rise in the elderly (Faul et al., 2010), potentially due to fall-related brain injuries. Given the above, the epidemiology of TBI will continue to change and require ongoing investigation. Improving and updating our understanding of the epidemiology of TBI provides the backdrop necessary for more downstream lines of research, which require an understanding of the scale of brain injury, such as prevention, treatment, and management.

\section{LIMITATIONS}

Our review, similar to other citation studies, is subject to a number of limitations. Chief among these is the possibility that our search terms, albeit comprehensive, did not permit identification of every one of the top-cited papers in TBI. However, because we used Harzing's Publish or Perish (Harzing, 2007) for our analysis, our search was biased toward inclusivity. This is because Harzing's Publish or Perish (Harzing, 2007) collects raw citation data through Google Scholar, which is more inclusive in terms of which journals it indexes than other search engines such as the Institute for Scientific Information (ISI) Web of Science, which indexes only ISI journals (Lipsman and Lozano, 2011). Furthermore, the citation metrics that were computed in the present review have likely changed since we completed our analyses, given that the TBI literature is being continually cited. Any recent citations of the papers included in the present review may alter the ranking of some of the top-cited articles in TBI, though the overall content of the two citation cohorts is unlikely to change substantially in short intervals of time.

Furthermore, recent years have seen a growth in the number of scientific publications related to TBI. A search of the Medical Subject Headings (MeSH) keywords "traumatic brain injury," "traumatic brain injuries," "concussion," and "concussions" in PubMed shows a stable growth in the number of TBI-related publications since 2004. In particular, between 2004 and 2013, 1733 TBI-specific papers were published, more than twice the 833 papers on brain injury published from 1994-2003. Therefore, as the citation rates we present do not control for general growth in the TBI field, our findings should be interpreted with caution.

There are also other measures of citation impact, including the h-index, g-index, and e-index. Although these metrics have unique value (Zhang, 2009, 2010), we did not include them in the present review, as we were not investigating citations by author or across specialties, institutions, or countries. We also did not control for the effects of self-citation or differences in citation practices across medical specialties (Kulkarni et al., 2007). Our review is also cross-sectional, and did not permit a longitudinal investigation. Future citation studies using alternative citation metrics and/or evaluating citation trends over time may be of additional value.

\section{CONCLUSION}

The present review provides a cross-sectional summary of some of the most influential studies in TBI, highlighting areas of research that require further investigation and development. Although studies on severe brain injury and predictors of outcome following TBI have been cited most extensively, the current research focus appears to be on mild TBI and investigating treatment strategies for brain injury. Our review is not designed to supplant systematic reviews or meta-analyses in TBI, but rather synthesize the literature uniquely to permit a novel analysis of TBI research. As the TBI literature evolves, it will be important for future citation studies to re-evaluate existing patterns and trends within this growing field of research. 


\section{REFERENCES}

Carroll, L. J., Cassidy, J. D., Holm, L., Kraus, J., and Coronado, V. G. (2004). Methodological issues and research recommendations for mild traumatic brain injury: the WHO collaborating centre task force on mild traumatic brain injury. J. Rehabil. Med. 36, 113-125. doi:10.1080/16501960410023877

Charleswell, C., Ross, B., Tran, T., and Walsh, E. (2014). Traumatic brain injury: considering collaborative strategies for early detection and interventional research. J. Epidemiol. Community Health. doi:10.1136/jech-2014-204239

Chen, A. J., and D'Esposito, M. (2010). Traumatic brain injury: from bench to bedside to society. Neuron 66, 11-14. doi:10.1016/j.neuron.2010.04.041

Cusimano, M. D., Sharma, B., Lawrence, D. W., Ilie, G., Silverberg, S., and Jones, R. (2013). Trends in North American newspaper reporting of brain injury in ice hockey. PLoS ONE 8:e61865. doi:10.1371/journal.pone.0061865

European Commission. (2012). The International Initiative for Traumatic Brain Injury Research (InTBIR): Working Together to Improve Outcomes and Lessen the Global Burden of Traumatic Brain Injury by 2020. Geneva: European Commission.

Faul, M., Xu, L., Wald, M. M., and Coronado, V. G. (2010). Traumatic Brain Injury in the United States: Emergency Department Visits, Hospitalizations, and Deaths 2002-2006. Atlanta: Centers for Disease Control and Prevention.

Fleminger, S., Oliver, D. L., Lovestone, S., Rabe-Hesketh, S., and Giora, A. (2003). Head injury as a risk factor for Alzheimer's disease: the evidence 10 years on a partial replication. J. Neurol. Neurosurg. Psychiatr. 74, 857-862. doi:10.1136/ jnnp.74.7.857

Garfield, E. (1986). Which medical journals have the greatest impact? Ann. Intern Med. 105, 313-320. doi:10.7326/0003-4819-105-2-313

Gavett, B. E., Stern, R. A., Cantu, R. C., Nowinski, C. J., and McKee, A. C. (2010). Mild traumatic brain injury: a risk factor for neurodegeneration. Alzheimers Res. Ther. 2, 18. doi:10.1186/alzrt42

Gavett, B. E., Stern, R. A., and McKee, A. C. (2011). Chronic traumatic encephalopathy: a potential late effect of sport-related concussive and subconcussive head trauma. Clin. Sports Med. 30, 179-88, xi. doi:10.1016/j.csm.2010.09.007

Harzing, A. W. (2007). Publish or Perish. Available at: http://www.harzing.com/pop. htm

Holsinger, T., Steffens, D. C., Phillips, C., Helms, M. J., Havlik, R. J., Breitner, J. C., et al. (2002). Head injury in early adulthood and the lifetime risk of depression. Arch. Gen. Psychiatry 59, 17-22. doi:10.1001/archpsyc.59.1.17

Ibrahim, G. M., Snead, O. C. III, Rutka, J. T., and Lozano, A. M. (2012). The most cited works in epilepsy: trends in the "citation classics". Epilepsia 53, 765-770. doi:10.1111/j.1528-1167.2012.03455.x

Konrad, C., Geburek, A. J., Rist, F., Blumenroth, H., Fischer, B., Husstedt, I., et al. (2011). Long-term cognitive and emotional consequences of mild traumatic brain injury. Psychol. Med. 41, 1197-1211. doi:10.1017/S0033291710001728

Kulkarni, A. V., Busse, J. W., and Shams, I. (2007). Characteristics associated with citation rate of the medical literature. PLOS ONE 2:e403. doi:10.1371/journal. pone. 0000403

Langlois, J. A., Rutland-Brown, W., and Wald, M. M. (2006). The epidemiology and impact of traumatic brain injury: a brief overview. J. Head Trauma Rehabil. 21, 375-378. doi:10.1097/00001199-200609000-00001

Lefaivre, K. A., Shadgan, B., and O'Brien, P. J. (2010). 100 Most cited articles in orthopaedic surgery. Clin. Orthop. Relat. Res. 469, 1487-1497. doi:10.1007/ s11999-010-1604- 1

Lipsman, N., and Lozano, A. M. (2011). The most cited works in major depression: the "citation classics". J. Affect. Disord. 134, 39-44. doi:10.1016/j.jad.2011.05.031

Lipsman, N., and Lozano, A. M. (2012). Measuring impact in stereotactic and functional neurosurgery: an analysis of the top 100 most highly cited works and the citation classics in the field. Stereotact. Funct. Neurosurg. 90, 201-209. doi:10.1159/000337170

Lipsman, N., Woodside, D. B., and Lozano, A. M. (2014). Trends in anorexia nervosa research: an analysis of the top 100 most cited works. Eur. Eat. Disord. Rev. 22, 9-14. doi:10.1002/erv.2270

Maas, A. I., Menon, D. K., Lingsma, H. F., Pineda, J. A., Sandel, M. E., and Manley, G. T. (2012). Re-orientation of clinical research in traumatic brain injury: report of an international workshop on comparative effectiveness research. $J$ Neurotrauma 29, 32-46. doi:10.1089/neu.2010.1599

Maas, A. I., Stocchetti, N., and Bullock, R. (2008). Moderate and severe traumatic brain injury in adults. Lancet Neurol. 7, 728-741. doi:10.1016/S1474-4422(08) 70164-9

Masel, B. E., and DeWitt, D. S. (2010). Traumatic brain injury: a disease process, not an event. J. Neurotrauma 27, 1529-1540. doi:10.1089/neu.2010.1358
McCauley, S. R., Boake, C., Levin, H. S., Contant, C. F., and Song, J. X. (2001). Postconcussional disorder following mild to moderate traumatic brain injury: anxiety, depression, and social support as risk factors and comorbidities. J. Clin. Exp. Neuropsychol. 23, 792-808. doi:10.1076/jcen.23.6.792.1016

Morton, M. V., and Wehman, P. (1995). Psychosocial and emotional sequelae of individuals with traumatic brain injury: a literature review and recommendations. Brain Inj. 9, 81-92. doi:10.3109/02699059509004574

Patsopoulos, N. A., Analatos, A. A., and Ioannidis, J. P. (2005). Relative citation impact of various study designs in the health sciences. JAMA 293, 2362-2366. doi:10.1001/jama.293.19.2362

Plassman, B. L., Havlik, R. J., Steffens, D. C., Helms, M. J., Newman, T. N., Drosdick, D., et al. (2000). Documented head injury in early adulthood and risk of Alzheimer's disease and other dementias. Neurology 55, 1158-1166. doi:10.1212/WNL.55.8.1158

Ponce, F. A., and Lozano, A. M. (2010). Highly cited works in neurosurgery. Part I: the 100 top-cited papers in neurosurgical journals. J. Neurosurg. 112, 223-232. doi:10.3171/2009.12.JNS091599

Ponsford, J., Bayley, M., Wiseman-Hakes, C., Togher, L., Velikonja, D., McIntyre, A., et al. (2014a). INCOG recommendations for management of cognition following traumatic brain injury, part II: attention and information processing speed. J. Head Trauma Rehabil. 29, 321-337. doi:10.1097/HTR. 0000000000000072

Ponsford, J., Janzen, S., McIntyre, A., Bayley, M., Velikonja, D., and Tate, R. (2014b). INCOG recommendations for management of cognition following traumatic brain injury, part I: posttraumatic amnesia/delirium. J. Head Trauma Rehabil. 29, 307-320. doi:10.1097/HTR.0000000000000074

Powell, J. M., Machamer, J. E., Temkin, N. R., and Dikmen, S. S. (2001). Self-report of extent of recovery and barriers to recovery after traumatic brain injury: a longitudinal study. Arch. Phys. Med. Rehabil. 82, 1025-1030. doi:10.1053/apmr. 2001.25082

Rubin, R. (2004). Foundations of Library and Information Science. Chicago: NealSchuman Publishers Inc.

Seel, R. T., Kreutzer, J. S., Rosenthal, M., Hammond, F. M., Corrigan, J. D., and Black, K. (2003). Depression after traumatic brain injury: a national institute on disability and rehabilitation research model systems multicenter investigation. Arch. Phys. Med. Rehabil. 84, 177-184. doi:10.1053/apmr.2003.50106

Shadgan, B., Roig, M., Hajghanbari, B., and Reid, W. D. (2010). Top-cited articles in rehabilitation. Arch. Phys. Med. Rehabil. 91, 806-815. doi:10.1016/j.apmr.2010. 01.011

Stern, R. A., Riley, D. O., Daneshvar, D. H., Nowinski, C. J., Cantu, R. C., and McKee, A. C. (2011). Long-term consequences of repetitive brain trauma: chronic traumatic encephalopathy. PM R 3, S460-S467. doi:10.1016/j.pmrj.2011.08.008

Stiefel, M. F., Spiotta, A., Gracias, V. H., Garuffe, A. M., Guillamondegui, O., MaloneyWilensky, E., et al. (2005). Reduced mortality rate in patients with severe traumatic brain injury treated with brain tissue oxygen monitoring. J. Neurosurg. 103, 805-811. doi:10.3171/jns.2005.103.5.0805

Strauss, A., and Corbin, J. M. (1990). Basics of Qualitative Research: Grounded Theory Procedures and Techniques. Thousand Oaks, CA: Sage Publications.

The Lancet. (2012). The changing landscape of traumatic brain injury research. Lancet Neurol. 11, 651. doi:10.1016/S1474-4422(12)70166-7

The Lancet Neurology. (2013). A rally for traumatic brain injury research. Lancet Neurol. 12, 1127. doi:10.1016/S1474-4422(13)70266-7

Tosetti, P., Hicks, R. R., Theriault, E., Phillips, A., Koroshetz, W., and Draghia-Akli, R. (2013). Toward an international initiative for traumatic brain injury research J. Neurotrauma 30, 1211-1222. doi:10.1089/neu.2013.2896

Velikonja, D., Tate, R., Ponsford, J., McIntyre, A., Janzen, S., and Bayley, M. (2014). INCOG recommendations for management of cognition following traumatic brain injury, part V: memory. J. Head Trauma Rehabil. 29, 369-386. doi:10.1097/HTR.0000000000000069

World Heath Organization. (2002). Projection of Mortality and Burden of Disease to 2030: Deaths by Income Group. Geneva: World Heath Organization.

Yang, H., and Pan, B. (2006). Citation classics in fertility and sterility, 1975-2004. Fertil. Steril. 86, 795-7, 797.e1-6. doi:10.1016/j.fertnstert.2006.07.1477

Zhang, C. T. (2009). The e-index, complementing the h-index for excess citations. PLOS ONE 4:e5429. doi:10.1371/journal.pone.0005429

Zhang, C. T. (2010). Relationship of the h-index, g-index, and e-index. J. Am. Soc. Inf. Sci. Technol. 61, 625-628.

Zitnay, G. A., Zitnay, K. M., Povlishock, J. T., Hall, E. D., Marion, D. W., Trudel, T., et al. (2008). Traumatic brain injury research priorities: the Conemaugh 
international brain injury symposium. J. Neurotrauma 25, 1135-1152. doi:10. 1089/neu.2008.0599

Conflict of Interest Statement: The authors declare that the research was conducted in the absence of any commercial or financial relationships that could be construed as a potential conflict of interest.

Received: 08 July 2014; accepted: 12 October 2014; published online: 05 November 2014 .
Citation: Sharma B and Lawrence DW (2014) Top-cited articles in traumatic brain injury. Front. Hum. Neurosci. 8:879. doi: 10.3389/fnhum.2014.00879

This article was submitted to the journal Frontiers in Human Neuroscience.

Copyright (c) 2014 Sharma and Lawrence. This is an open-access article distributed under the terms of the Creative Commons Attribution License (CC BY). The use, distribution or reproduction in other forums is permitted, provided the original author(s) or licensor are credited and that the original publication in this journal is cited, in accordance with accepted academic practice. No use, distribution or reproduction is permitted which does not comply with these terms. 